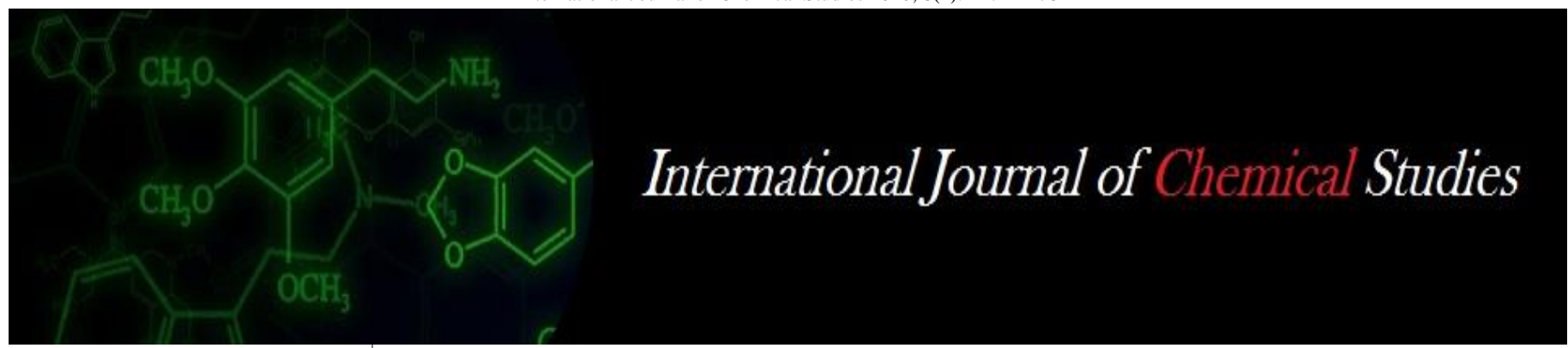

P-ISSN: 2349-8528

E-ISSN: 2321-4902

IJCS 2020; 8(1): 1274-1278

(C) 2020 IJCS

Received: 06-11-2019

Accepted: 10-12-2019

Uma Kant Singh

Dept. of Horticulture, BAU,

Sabour, Bhagalpur, Bihar-India

Devi Singh

Dept. of Horticulture, Sam

Higginbottom Institute of

Agriculture, Technology and

Sciences, Allahabad-India

Indra Deo Prasad

Dept. of Horticulture, BAU,

Sabour, Bhagalpur, Bihar-India

Corresponding Author:

Uma Kant Singh

Dept. of Horticulture, BAU,

Sabour, Bhagalpur, Bihar-India

\section{Estimation of fruit quality parameters in different genotypes of bitter gourd (Momordica charantia L.)}

\section{Uma Kant Singh, Devi Singh and Indra Deo Prasad}

DOI: https://doi.org/10.22271/chemi.2020.v8.i1r.8431

\section{Abstract}

Study of 40 genotypes of Bitter gourd was carried out during Kharif season 2014 and 2015 in central Uttar Pradesh, India to study the association among fruit quality and their direct and indirect influence on total marketable fruit yield and income. Observations were recorded on Total Soluble Solid (TSS) and vitamin $\mathrm{C}$ content and data analyzed statistically. Comparatively higher total soluble solid was recorded in IC-085626 (4.96 \& 5.58) and maximum Vitamin 'C' was recorded in IC-085612 (81.05 \& 81.57) followed by IC-085616 (80.49 \& 81.04) and IC-085622 (76.67 \& 79.88) which were statistically at par with each other and significantly higher from the check germplasms. Minimum Vitamin ' $C$ ' was recorded in PBIG-5 (70.47 \& 71.20) during both the years of investigation. It was possibly due to genotypic and phenotypic characters of the germplasms respectively during both the years of investigation suggesting most efficient as well as highly profitable.

Keywords: Bitter gourd, germplasms, fruit quality TSS and Vitamin C.

\section{Introduction}

Bitter gourd (Momordica charantia L.) is one of the most important and widely used cucurbitaceous summer vegetables in India. It belongs to the family Cucurbitaceae. Most of the authors agree that India or Indo-Malayan region is the original home of bitter gourd (Bose and Som, 1986) ${ }^{[42]}$. Bitter gourd is widely distributed in China, Malaysia, India, Tropical Africa and north and South America. In India, Karnataka, Maharashtra, Tamil Nadu and Kerala are the major bitter gourd growing states. The crop is cultivated over an area of 83 thousand hectare in India with production of 906 thousand metric tons with productivity of 10.91 metric ton per hectare. Selection of a high yielding germplasms can therefore significantly increase the bitter gourd production. Like any other crops, yield in bitter gourd is a complex component character. Vegetables are known for its nutritional, medicinal and curative properties. India is the second largest producers of vegetable with $2.8 \%$ of total cropped area under vegetables. India has been bestowed with wide range of climate and physio-geographical conditions which ensures availability of most kind of vegetables. It ranks second in vegetables production in the world, after China. As per National Horticulture Database, India produced 166.466 million metric tonnes of vegetables. The area under cultivation of vegetables was 9.299 million hectares having productivity 17.89 metric tons per hectare (NHB database 2015-16). India is also a prominent exporter of dried and preserved vegetables to the world. The country has exported 56,158.40 MT of dried and preserved vegetables worth of Rs. 4,866.9 crores during the year 2015-16. (Source: APEDA). Presently the growth rate of vegetable production in our country is $2.60 \%$. However, the daily requirement of vegetable per day per capita is $300 \mathrm{~g}$ but availability of vegetable is $210 \mathrm{~g}$. Traditionally Indian dietary system is based on cereals and pulses leaving little space for vegetables. It was potato which first made in road into our dietary habits. However, gradually increasing consciousness towards balanced diet and its lasting effect on health of the masses gave way to vegetables on our dishes. It is not a wonder that in a very short span of time, in some quarters, vegetable has occupied prime place as a stable food in our dietary system. Amongst all the vegetables, bitter gourd (Momordica charantia L.) pose a gloving example of how conscious are the masses towards their health. By dint of its bitter taste all most all the children and major chunk of adults refrained from over to 
accommodating bitter gourd in their diet for a very long time. But, its medicinal values gradually went on attracting more and more people, which ultimately helped in developing a special taste for this vegetable not only amongst adults but in children too. If one strains his brain in remembering the share once bitter gourd occupied in shelves of vegetable shops a decade or two back and what it is now, he will wonder about the miraculous change. Now a day, bitter gourd can be seen in vegetable shops round the year and in substantial quantum.

Attention towards planned breeding programme and developing agro-techniques for particular vegetable results from demand and availability phenomenon. Quite naturally, bitter gourd attracted, attention of scientists quite lately and thus, little has been done so for towards evolving high yielding varieties and production oriented agro-techniques in bitter gourd. The characterization of germplasms by agromorphological traits helps the plant breeders to select the accessions to be utilized in hybridization programme (Ghafoor et al., 2002). Thus, effective improvement in yield may be brought about through selection of various yield component characters, which show association among themselves and also with yield (Gupta et al., 2015) ${ }^{[8]}$.

Bitter gourd (Momordica charantia L.) having high nutritional value especially ascorbic acid and iron (Behera, 2004). The fruits are used as tonic, stimulant, purgative, stomachic carminative, antiheminthic, anti-inflammatory, febrifuge, vulnerary, stimulant, thermogenic, antidiabetic, etc (Longmam, 1995). During the past decades, the antidiabetic properties of the crop have been studied extensively and a hypoglycemic principle called charantin has been isolated. The bitter ingredient in bitter gourd is "mormodicine", an alkaloid which is different from cucurbitacin present in other genera of cucurbits.

The fruit of bitter gourd contains $1.6 \mathrm{~g}$ protein, $1.8 \mathrm{mg}$ iron, $20 \mathrm{mg}$ of calcium, $88 \mathrm{mg}$ of vitamin C, $70 \mathrm{mg}$ of phosphorous and 126 I.U. of vitamin A in $100 \mathrm{~g}$ of edible portion. (Fageria et al., 2003). It has also some medicinal value being easily digestible, diuretic and laxative invigorates the heart and brain and is useful in the disorder of the blood circulatory system. (Rice et al., 1992; Yawalkar, 1985). In India, vegetable production is not uniformly distributed round the year due to climate and edaphic factors and most of the vegetables are produced in winter. So, there is a scarcity of vegetables during summer or rainy season and only small amount of vegetables are produced during the months of April to October. Among these, bitter gourd contributes a significant portion of vegetable production during lean period in summer season of India.

\section{Material and Methods}

The investigation was carried out in central region of Uttar Pradesh during 2014 and 2015 for screening the different genotypes of bitter gourd (Momordica charantia L.) to find the association between fruit quality parameter under farm condition. The experimental is at elevation of $98 \mathrm{~m}$ above sea level at $28.87^{\circ} \mathrm{N}$ latitude and $81.15^{\circ} \mathrm{E}$ longitude. The characteristics of the soil are sandy loam in order to Inceptisol soil. The research area has a sub-tropical climate with extremes of summer and winter. During the summer season, the temperature reaches upto 46-480C, while during winter season, especially in the month of Nov. and Jan. temperature drops down to as low as 1-200C. During winter, frost and during summer, hot scorching wind are common features. The average rainfall in this area is around $882 \mathrm{~mm}$, during the monsoon i.e. June to Sept, with a few occasional light showers and drizzles are seen in the winter also. The crop was grown under normal season. Total 40 genotypes of bitter gourd collected from different parts of the country and experiment was laid out in a completely randomized block design (CRBD) with three replications. The plant was shown at a spacing of $1.5 \mathrm{~m} \mathrm{X} 0.75$ meter with net plot size $7.5 \mathrm{~m} \mathrm{X}$ $3 \mathrm{~m}$. In the present study, 40 genotypes of bitter gourd collected from different parts of the country and experiment was laid out in a randomized block design with three replications. The experiment comprising 40 genotypes viz., IC- 085608(IIVR), IC-085609(IIVR), IC-085610 (IIVR), IC085611(IIVR), IC-085612(IIVR), IC- 085625(IIVR), IC085613(IIVR), IC-085614 (IIVR), IC-085626(IIVR), IC085615(IIVR), IC- 085616(IIVR), IC-085617(IIVR), IC085618 (IIVR), IC-085619(IIVR), IC-085620(IIVR), IC085621(IIVR), IC-085622(IIVR), IC-085623 (IIVR), IC085624(IIVR), HABG-29(RCER, Ranchi), HABG-30(RCER, Ranchi), IC-085627 (IIVR), IC-085628(IIVR), IC085629(IIVR), IC- 085630(IIVR), IC-085631(IIVR), IC085632 (IIVR), IC-085633(IIVR), PBIG-1(Pantnagar), PBIG3 (Pantnagar), PBIG-4 (Pantnagar), PBIG-5 (Pantnagar), PBIG-6 (Pantnagar), PBIG-7 (Pantnagar), IC-085634(IIVR), IC-085635(IIVR), IC-085636(IIVR), IC-085638(IIVR), IC08563 9(IIVR) and PBIG-2(Check). Observations were recorded on various fruit quality parameter under farm condition to screen out superior genotypes.

\section{Result and Discussion \\ Total soluble solid $\left(\right.$ Brix $\left.^{\circ}\right)$}

Total soluble solid of bitter gourd as affected by different germplasms during both the years of investigation and presented in Table 1. Variation in total soluble solid among different genotypes was found significant during both the years of 2014 and 2015. During first year, significantly minimum total soluble solid was recorded in PBIG-2 (3.43) followed by IC-085622 (3.77), IC-085616 (3.85) and IC085612 (3.98). However, during second year, minimum total soluble solid was recorded by PBIG-2 (3.44) followed by PBIG-1 (3.58), PBIG-5 (3.92) and IC-085616 (4.17) which was statistically at par with each other. Maximum total soluble solid was recorded by IC-085626 (4.96 \& 5.58) during both the years of investigation. It was possibly due to genotypic and phenotypic characters of the germplasms.

Table 1: Effect of different genotypes of bitter gourd on Total Soluble Solid (Brix ${ }^{\circ}$ ) during 2014 and 2015.

\begin{tabular}{|c|c|c|c|}
\hline \multirow{2}{*}{ Genotypes } & Total Soluble Solid (Brix ${ }^{\circ}$ ) & \multirow{2}{*}{ Pooled } \\
\cline { 2 - 4 } & $\mathbf{2 0 1 4}$ & $\mathbf{2 0 1 5}$ & 4.91 \\
\hline IC-085608 & 4.54 & 5.28 & 4.33 \\
\hline IC-085609 & 4.28 & 4.37 & 4.83 \\
\hline IC-085610 & 4.47 & 5.17 & 4.99 \\
\hline IC-085611 & 4.57 & 5.40 & \\
\hline \multicolumn{2}{|c}{$\sim 1275 \sim$}
\end{tabular}




\begin{tabular}{|c|c|c|c|}
\hline IC-085612 & 3.98 & 4.35 & 4.17 \\
\hline IC-085625 & 4.65 & 5.37 & 5.01 \\
\hline IC-085613 & 4.59 & 4.95 & 4.77 \\
\hline IC-085614 & 4.84 & 5.16 & 5.00 \\
\hline IC-085626 & 4.96 & 5.58 & 5.27 \\
\hline IC-085615 & 4.51 & 4.37 & 4.44 \\
\hline IC-085616 & 3.85 & 4.17 & 4.01 \\
\hline IC-085617 & 4.72 & 4.92 & 4.83 \\
\hline IC-085618 & 4.24 & 5.20 & 4.73 \\
\hline IC-085619 & 4.71 & 5.38 & 5.05 \\
\hline IC-085620 & 4.34 & 5.11 & 4.73 \\
\hline IC-085621 & 4.68 & 4.84 & 4.77 \\
\hline IC-085622 & 3.77 & 4.38 & 4.08 \\
\hline IC-085623 & 4.03 & 4.83 & 4.43 \\
\hline IC-085624 & 4.56 & 5.25 & 4.91 \\
\hline HABG-29 & 4.10 & 4.29 & 4.20 \\
\hline HABG-30 & 4.14 & 4.73 & 4.44 \\
\hline IC-085627 & 4.19 & 4.36 & 4.28 \\
\hline IC-085628 & 4.48 & 4.67 & 4.58 \\
\hline IC-085629 & 4.63 & 4.86 & 4.75 \\
\hline IC-085630 & 4.55 & 4.93 & 4.75 \\
\hline IC-085631 & 4.57 & 4.85 & 4.72 \\
\hline IC-085632 & 4.40 & 4.38 & 4.39 \\
\hline IC-085633 & 4.35 & 4.52 & 4.44 \\
\hline PBIG-1 & 4.29 & 3.58 & 3.94 \\
\hline PBIG-3 & 4.89 & 4.30 & 4.60 \\
\hline PBIG-4 & 4.57 & 4.28 & 4.43 \\
\hline PBIG-5 & 4.42 & 3.92 & 4.18 \\
\hline PBIG-6 & 4.61 & 4.60 & 4.61 \\
\hline PBIG-7 & 4.38 & 4.48 & 4.44 \\
\hline IC-085634 & 4.80 & 4.83 & 4.82 \\
\hline IC-085635 & 4.83 & 4.17 & 4.50 \\
\hline IC-085636 & 4.72 & 4.72 & 4.72 \\
\hline IC-085638 & 4.44 & 4.45 & 4.45 \\
\hline IC-085639 & 4.82 & 4.63 & 4.73 \\
\hline PBIG-2(Check) & 3.43 & 3.44 & 3.44 \\
\hline Mean & 4.45 & 4.68 & 4.56 \\
\hline C.V. & 8.6009 & 3.9760 & 4.9986 \\
\hline S.E. & 0.2210 & 0.1075 & 0.1863 \\
\hline C.D. $5 \%$ & 0.6223 & 0.3026 & 0.3710 \\
\hline
\end{tabular}

Table 2: Effect of different genotypes of bitter gourd on vitamin 'C' (mg / 100gm) during 2014 and 2015.

\begin{tabular}{|c|c|c|c|}
\hline \multirow{2}{*}{ Genotypes } & \multicolumn{2}{|c|}{ Vitamin 'C' (mg / 100 gm) } & \multirow{2}{*}{ Pooled } \\
\cline { 2 - 3 } & $\mathbf{2 0 1 4}$ & $\mathbf{2 0 1 5}$ & 73.98 \\
\hline IC-085608 & 72.49 & 73.46 & 73.83 \\
\hline IC-085609 & 72.67 & 73.65 & 75.75 \\
\hline IC-085610 & 74.66 & 75.17 & 74.06 \\
\hline IC-085611 & 72.74 & 73.71 & 71.65 \\
\hline IC-085612 & 81.05 & 81.57 & 73.93 \\
\hline IC-085625 & 72.60 & 73.57 & 73.39 \\
\hline IC-085613 & 73.54 & 74.51 & 75.14 \\
\hline IC-085614 & 71.90 & 72.86 & 73.29 \\
\hline IC-085626 & 74.15 & 75.13 & 81.10 \\
\hline IC-085615 & 72.64 & 73.60 & 75.91 \\
\hline IC-085616 & 80.49 & 81.04 & 72.70 \\
\hline IC-085617 & 74.91 & 75.90 & 73.08 \\
\hline IC-085618 & 71.29 & 72.78 & 74.10 \\
\hline IC-085619 & 70.83 & 73.19 & 78.78 \\
\hline IC-085620 & 71.30 & 73.51 & 73.88 \\
\hline IC-085621 & 72.68 & 74.84 & 73.68 \\
\hline IC-085622 & 76.67 & 79.88 & 72.91 \\
\hline IC-085623 & 71.93 & 74.49 & 75.48 \\
\hline IC-085624 & 72.50 & 73.86 & 75.91 \\
\hline HABG-29 & 72.10 & 72.71 & \\
\hline HABG-30 & 74.35 & 75.27 & 74.93 \\
\hline IC-085627 & 74.88 & & \\
\hline
\end{tabular}




\begin{tabular}{|c|c|c|c|}
\hline IC-085628 & 72.79 & 73.06 & 73.43 \\
\hline IC-085629 & 75.69 & 75.11 & 76.57 \\
\hline IC-085630 & 76.25 & 76.76 & 77.18 \\
\hline IC-085631 & 73.34 & 74.30 & 74.49 \\
\hline IC-085632 & 75.06 & 75.82 & 75.94 \\
\hline IC-085633 & 71.42 & 72.38 & 72.57 \\
\hline PBIG-1 & 71.44 & 72.10 & 71.78 \\
\hline PBIG-3 & 72.27 & 72.96 & 72.62 \\
\hline PBIG-4 & 73.54 & 73.79 & 73.67 \\
\hline PBIG-5 & 70.47 & 71.20 & 70.84 \\
\hline PBIG-6 & 71.73 & 72.00 & 71.87 \\
\hline PBIG-7 & 72.41 & 71.93 & 72.18 \\
\hline IC-085634 & 71.05 & 71.26 & 71.16 \\
\hline IC-085635 & 72.44 & 72.78 & 72.62 \\
\hline IC-085636 & 75.72 & 75.87 & 75.80 \\
\hline IC-085638 & 74.62 & 74.84 & 74.73 \\
\hline IC-085639 & 74.09 & 74.32 & 74.21 \\
\hline PBIG-2(Check) & 75.22 & 75.03 & 75.13 \\
\hline Mean & 73.55 & 74.38 & 74.40 \\
\hline C.V. & 2.1362 & 4.1557 & 1.4580 \\
\hline S.E. & 0.9071 & 1.7847 & 0.8857 \\
\hline C.D. 5\% & 2.5540 & 5.0247 & 1.7634 \\
\hline
\end{tabular}

\section{Vitamin ' $\mathrm{C}$ ' (mg/100 gm)}

Vitamin ' $\mathrm{C}$ ' of bitter gourds in different germplasms during both the years of investigation have been presented in Table2 The data revealed that the amount of Vitamin ' $\mathrm{C}$ ' present in different germplasms were significantly different during both the years. Maximum Vitamin ' $\mathrm{C}$ ' was recorded in IC-085612 (81.05 \& 81.57) followed by IC-085616 (80.49 \& 81.04) and IC-085622 (76.67 \& 79.88) which were statistically at par with each other and significantly higher from the check germplasms. Minimum Vitamin ' $\mathrm{C}$ ' was recorded in PBIG-5 (70.47 \& 71.20) during both the years of investigation. It was possibly due to genotypic and phenotypic characters of the germplasms.

\section{Conclusion}

On the basis of the result of present study, it can be concluded that genotypes like accession IC- 085612(IIVR) have the highest vitamin $\mathrm{C}$ content followed by IC-085616 (IIVR) and IC-085622 (IIVR) under climatic condition of central Uttar Pradesh. The results also found variations in yield attributes which created great potentiality for developing high yielding and quality bitter gourd through breeding.

\section{Acknowledgment}

The authors are grateful to the Naini Institute Agriculture. Sam Higginbottom University of Agriculture Technology and Sciences, (Formerly Allahabad Agriculture Institute), Allahabad, India for providing all necessary helps and facilities during the course of experiment and valuable comments of anonymous reviewers helped us a lot to improve this manuscript.

\section{References}

1. Abusaleha, Dutta CP. Study on variability, heritability and genetic advance in bitter gourd. J. Maharashtra Agric. Univ. 1990; 15(3):333-334.

2. Ahmed MS, Rasul MG, Bashar MK, Masuduzzaman A SM, Mian MAK. Variability and heterosis in bitter gourd. Indian J. Hort. 2000; 13(1):27-32.
3. Anonymous. Food and Agricultural Organization of the United Nations, Soil Survey Project of Bangladesh. Soil Res. Tech. Rep. pp, 1971; 101-159.

4. Badade DS, Warade SD, Gaikwad SK. Genetic divergence in bitter gourd. J. Maharashtra Agric. Univ. 2001; 26(2):137-139.

5. Burton GW. Quantitative Inheritance in Grasses, Proc. 6th. Int. Grassland. Cong. 1952; 1:277-283.

6. Choudhury B. Vegetables. National Book Trust, A-5 Green Park, New Delhi, India, 1990; 147-159.

7. Dora DK, Acharya GC, Das S. Genetic divergence in bitter gourd. Veg. Sci. 2001; 28-(2):170-171.

8. Gupta NML, Bhardwaj S.P. Singh, Sood S. Correlation and path analysis of yield and yield components in some genetic stocks of bitter gourd (Momordica charantia L.) SABRAO Journal of Breeding and Genetics. 2015; 47: 475-481.

9. Gill BS, Kumar JC. Variability in genetic stock and heritable components in bitter gourd. Res. Punjab Agric. Univ. 1986; 23(4):583-588.

10. Gomez KA, Gomez AA. Statistical Procedure for Agricultural Research. John Wiley and Sons. Inc. New York. 1984; 67-215.

11. Gopalan C, Ramasastri BV, Balasubramanian SC. Nutritive value of Indian foods. India Council of Medical Research. National Institute of Nutrition, Hyderabad, 1982, 24.

12. Hazra $P$, Ghosh $R$, Nath-Subhadeep, Nath $S$. Identification of important yield components in bitter gourd. Crop Res. Hisar. 2003; 25(2):244-252.

13. Indiresh BT. Studies on genotypic variability in bitter gourd (Momordica Charantia). Thesis Abstr. 1982; $8(1): 52$.

14. Resmi J, Sreelathakumary I. Multivariate analysis of the genetic diversity of bitter gourd (Momordica charantia L.) Vegetable Science. 2012; 39(1):26-30.

15. Jagadev PN, Samal KM, Lenka L. Genetic divergence in bitter gourd. Indian J. Genet. 2012; 51:465-466.

16. Jeshwani LM, Murty BR, Melira RB. Divergence in relation to geographical origin in world collection in bitter gourd. Indian J. Genet. 1970; 30:11-25. 
17. Kumar R, Brahmachari VS, Kumar R. Varietal assessment of bitter gourdin Diara area of Bihar. Hort. J. 1995; 8(2):165-168.

18. Kumaran SS, Natarajan S, Thamburoj S. Correlation and path analysis studies in bitter gourd. South Indian Hort. 1998; 46(3-6):138-142.

19. Lalta P, Gautan NC, Singh SP. Studies on genetic variability and character association in bitter gourd. Veg. Sci. 1988; 15(1):86-94.

20. Mathew SM, Gopalakrishan PK, Peter KV. Genetic distance among five botanical varieties of bitter gourd. Agric. Res. J. Kerala. 1986; 24(2):195-196.

21. Mishra SN, Sahoo SC, Mishra RS. Variability for quantitative characters in bitter gourd. Orissa J. Hort. 1990; 18(1-2):75-79.

22. Mital RK, Singh HN, Srivastava JP. Genetic divergence in bitter gourd. Indian J. Fm. Sci. 1975; 3:22-27.

23. Prasad VSRK, Singh DP. Studies on heritability, genetic advance and correlation in bitter gourd. Indian J. Hort. 1989; 46(3):390-394.

24. Prasad VSRK, Singh DP. Studies of morphological component of bitter gourd. Indian J. Hort. 1990a; 47(3):537-540.

25. Prasad VSRK, Singh DP. Genotype $\mathrm{x}$ environment interaction in bitter gourd. Indian J. Hort. 1990; 47(1):7578.

26. Prasad VSRK, Singh DP, Singh RP. Biological divergence in the land races of bitter gourd. Indian J. Hort. 1993; 50(1):57-63.

27. Prasad VSR, Jain BP, Verma SPP, Ganguly DK. Diversity pattern and choice of parents of hybridization in bitter gourd. J. Res. Bires. Agril. Univ. 2001; 13(5):3339.

28. Rahman AFMM, Das MK, Haque MM. Variability, correlation and path coefficient analysis in bitter gourd. Bangladesh J. Agric. 1986; 11(3):13-19.

29. Rahman MM, Dey SK, Wazuddin M. Yield, yield components and plant characters of several bitter gourds, ribbed gourd, bottle gourd and sweet gourd genotype. BAU Res. Progress. 1990; 4:117-127.

30. Ram D. Non- hierarchical Euclidean cluster analysis in bitter gourd. Indian J. Hort. 2001; 58(3):264-268.

31. Ramachandran C, Gopalkrishan PK, Peter KV. Genetic divergence in bitter gourd. Veg. Sci. 1981; 7:100-104.

32. Rao CR. Advanced Statistical Methods in Biometrical Research. John Wiley and Sons, New York. 1952; 45110.

33. Rasheed MM, Nabi SA, Rasul MG, Mian MAK. Genetic divergence in bitter gourd. Bangladesh J. Plant Breed. Genet. 2002; 15(1):39-41.

34. Rashid MM. Vegetable Science (in Bangla). 1st ed., Bangla Academy, Dhaka. Bangladesh. 1993; 333-336.

35. Rashid MM. Vegetable Science (in Bangla).1st ed., Bangla Academy, Dhaka. Bangladesh. 1999; 333-336.

36. Rice RP, Rice LW, Tridall HD. Fruit and vegetable production in warm climates. The MacMillan Press Ltd. London, pp. 1982; 257-258.

37. Sachan SCP, Mehta ML, Singh DP. Studies on floral biology of bitter gourd. Prog. Hort. 1989; 21(3-4):229234.
38. Saha MC, Begum RA, Hamid MM, Hossain SMM. Genetic variability and character association in bitter gourd. Indian J. Hort. 1991; 19(4):509-515.

39. Saha RR, Mitra BN, Hossain AE, Jamaluddin M, MosiulHoque AMM. Genetic variability, character association and path coefficient analysis in bitter gourd. Indian J. Hort. 1992; 20(1):59-62.

40. Sarkar SK, Saha P, Maity TK, Som MG. Effect of growth regulators on induction of flowering and sex expression in seed propagated plants of bitter gourd. Indian J. Hort. 1989; 46(4):509-551.

41. Sarkar SK, Maity TK, Som MG. Correlation and path coefficient studies in bitter gourd. Indian J. Hort. 1999; 56(3):252-255.

42. Seshadri V. Cucurbits: In Vegetable Crop in India, ed. T.K. Bose, 1986, 6.

43. Shanmugavelu KG. Production Technology of Vegetable Crops. Oxford and IBH Pub. Co. New Delhi, India. 1989; 821-825.

44. Singh RK, Chaudhury BD. Biometrical methods of quantitative genetic analysis. Harayana J. Hort. Sci. 1985; 12(1):151-156.

45. Singh B, Singh AK, Kumar S. Genetic divergence studies in bitter gourd (Momordica charantia L.) Academic journal of plant science. 2013; 6(2):89-91.

46. Singh AK, Gautam NC, Singh KA. Genetic variability and correlation studies in bitter gourd. Indian J. Hort. 1985b; 42(3\&4):252-257.

47. Singh RR, Mishra GM, Jha RN. Studies on varieties and scopes for improvement in bitter gourd. South Indian Hort. 1985; 33(4):257-260.

48. Singh VP, Singh K, Jaiswal RC. Genetic variability and correlation studies in bitter gourd. Narendra Deva J. Agric. Res. 1986; 1(2):120-124.

49. Singh DP, Prasad VSRK. Variability and correlation studies in bitter gourd. Indian J. Hort. 1989; 46(2):204209.

50. Uddin MJ, Mitra BN. Variability of some quantitative characters in bitter gourd. Bangladesh J. Agric. Sci. 1994; 19:17-22.

51. Vashistha RN, Partap PS, Pandita ML. Studies on variability and heritability in, 1983. 